\title{
Detection of $P$ element transcripts in embryos of Drosophila melanogaster and D. willistoni
}

\author{
MONiCA L. BLAUTH ${ }^{1,2}$, RAFAELA V. BRUNO ${ }^{3}$, ELIANA ABDELHAY ${ }^{4}$, \\ ELGION L.S. LORETO ${ }^{2,5}$ and VERA L.S. VALENTE ${ }^{2,5}$ \\ ${ }^{1}$ Departamento de Ciências Biológicas, Universidade do Estado de Mato Grosso (UNEMAT) \\ Campus Tangará da Serra, Rodovia MT-358, km 07, Bairro Aeroporto \\ 78300-000 Tangará da Serra, MT, Brasil \\ ${ }^{2}$ Laboratório de Drosophila, Departamento de Genética, Instituto de Biociências \\ Universidade Federal do Rio Grande do Sul (UFRGS), Caixa Postal 15053 \\ 91501-970 Porto Alegre, RS, Brasil \\ ${ }^{3}$ Laboratório de Biologia Molecular de Insetos, Fundação Oswaldo Cruz, Av. Brasil, 4365 \\ Bairro Manguinhos, 21045-900 Rio de Janeiro, RJ, Brasil \\ ${ }^{4}$ Centro de Transplante de Medula Óssea, Instituto Nacional de Câncer \\ Praça da Cruz Vermelha, 23, $7^{\circ}$ andar, 20230-130 Rio de Janeiro, RJ, Brasil \\ ${ }^{5}$ Departamento de Biologia, Centro de Ciências Naturais e Exatas, Universidade Federal de Santa Maria, \\ Caixa Postal 5050, Agência Universitária, 97111-970 Santa Maria, RS, Brasil \\ Manuscript received on August 28, 2008; accepted for publication on March 11, 2009; \\ contributed by VERA L.S. VALENTE*
}

\begin{abstract}
The $P$ element is one of the most thoroughly studied transposable elements (TE). Its mobilization causes the hybrid dysgenesis that was first described in Drosophila melanogaster. While studies of the $P$ element have mainly been done in D. melanogaster, it is believed that Drosophila willistoni was the original host species of this TE and that $P$ was transposed to the $D$. melanogaster genome by horizontal transfer. Our study sought to compare the transcriptional behavior of the $P$ element in embryos of $D$. melanogaster, which is a recent host, with embryos of two strains of $D$. willistoni, a species that has contained the $P$ element for a longer time. In both species, potential transcripts of transposase, the enzyme responsible for the TE mobilization, were detected, as were transcripts of the $66-\mathrm{kDa}$ repressor, truncated and antisense sequences, which can have the ability to prevent TEs mobilization. The truncated transcripts reveal the truncated $P$ elements present in the genome strains and whose number seems to be related to the invasion time of the genome by the TE. No qualitative differences in antisense transcripts were observed among the strains, even in the $D$. willistoni strain with the highest frequency of heterochromatic $P$ elements.
\end{abstract}

Key words: Drosophila, D. willistoni, hybrid dysgenesis, RNAi, $P$ element, transposable element.

\section{INTRODUCTION}

The $P$ element is the most thoroughly studied transposable element (TE) in Drosophila. It was first discovered as the causative agent of hybrid dysgenesis in Drosophila melanogaster (Kidwell 1977). Later, other

\footnotetext{
* Member Academia Brasileira de Ciências Correspondence to: Vera Lúcia da Silva Valente E-mail: vera.valente@bol.com.br/vera.gaiesky@ufrgs.br
}

elements, including transposons and retroelements, were identified as also being able to promote a similar syndrome in D. melanogaster and in other species of the genus (Yannopoulos et al. 1987, Crozatier et al. 1988, Lozovskaya et al. 1990, Petrov et al. 1995, Evgen'ev et al. 1997). The syndrome caused by the $P$ element affects the germ cells of the offspring from crosses be- 
tween males of strains that contain functional $P$ elements in the genome and females that do not (Kidwell and Kidwell 1979, Engels 1989). This syndrome promotes sterility and gonadal atrophy.

The $P$ element is a class II TE that is $2.9 \mathrm{~kb}$ long, including the 31-bp Inverted Terminal Repeats (ITR), and is transposed by the DNA cut and paste mechanism (Misra and Rio 1990, Laski et al. 1986). The $P$ element contains four open reading frames (ORFs) that encode at least two proteins by alternative splicing of the third intron, named IVS3. The transposase, an 87$\mathrm{kDa}$ enzyme necessary for transposition, is expressed exclusively in the germline cells (Siebel and Rio 1990). In somatic cells, the IVS3 sequence is retained in the transcript and a $66-\mathrm{kDa}$ repressor protein is instead produced.

The $P$ element is widely dispersed in Neotropical species of the subgenus Sophophora (Daniels et al. 1990, Clark and Kidwell 1997, Loreto et al. 1998). This sequence is present in the cosmopolitan species D. melanogaster, but not in other species ranked under the melanogaster subgroup, suggesting a recent invasion of the D. melanogaster genome by horizontal transfer. This hypothesis is also supported by studies showing that several strains of D. melanogaster collected before the 1950s do not have the $P$ element (Bregliano and Kidwell 1983). The $P$ element sequences of $D$. willistoni and $D$. melanogaster differ by only a single nucleotide substitution (Daniels et al. 1990), suggesting that the donor species belongs to the willistoni group. The first contact between the two species is calculated to have occurred around the year 1800, when it is believed that $D$. melanogaster arrived in the New World (Engels 1989). Therefore, in a period of about 200 years, the $P$ element invaded the D. melanogaster genome and dispersed across the world.

The invasive capacity of the $P$ element has been attributed to its ability to regulate its own mobility, increasing the chances of host survival in the face of its invasion (Brookfield 1991). Besides the tissue-specific splicing of IVS3, other alternative forms of splicing into this intron, such as those described for D. melanogaster, D. bifasciata and D. helvetica by Chain et al. (1991) and Haring et al. (1998), as well as deleted copies, are considered as mechanisms that prevent $P$ elements from transposing. The KP protein, encoded by a truncated $P$ element sequence, is one of the most widely known repressors of $P$ element mobility. The short KP polypeptides may interact with the $P$ transposase and inhibit its function through the assembly of inactive heteromultimers (Lee et al. 1996, 1998). Alternatively, short $P$ polypeptides may interact with the $P$ element promoter, thus inhibiting transcription.

Simmons et al. (2002) suggested that the nature of the female $\mathrm{P}$ cytotype, which refers to the maternal ability to prevent the paternally originated $P$ element from transposing, is determined by the $66 \mathrm{kDa}$-repressor. A consensus sequence, similar to those found in the maternal genes, was identified in the IVS3 intron and appears to allow only unspliced transcripts to be maternally transmitted by the nurse cells to the oocyte, where they prevent transposase enzyme activity after egg fertilization. On the other hand, the most recent work of Josse et al. (2007) proposes the telomeric Trans-Silencing Effect (TSE), a mechanism by which a transposon inserted in subtelomeric heterochromatin or close to the centromere has the capacity to repress homologous transposons in the genome. The observed sensitivity to mutations in genes that code for the proteins AUBERGINE and PIWI suggested that the $\mathrm{P}$ cytotype might depend on repeat-associated small interfering RNA. The AUBERGINE and PIWI proteins link to small antisense RNAs and trigger the production of more antisense transcripts, which in turn prevent the expression of homologous sequences by sequence complementarity.

Considering these aforementioned studies, we investigated the presence of transcripts coding for transposase and potential repressors of mobilization of the $P$ element in embryos of two strains of $D$. willistoni, which produce offspring affected by hybrid dysgenesis syndrome and whose previous description detected the $P$ element inserted preferentially in heterochromatic in the Wip strain and in euchromatic in the 17A2 strain. These strains favor the study of the proposed hypothesis that correlates heterochromatin sequences with their transcriptions in an antisense way. Apart from this, one strain of D. melanogaster was included in our studies in an attempt to detect differences between old and new host species. 


\section{MATERIALS AND METHODS}

\section{FLY STOCKS}

The strains used were D. melanogaster Harwich (H) from the USA, first collected in the 1960s and normally used as a $P$ element-positive control in experiments; $D$. willistoni 17A2 from South Brazil $\left(30^{\circ} 05^{\prime} S, 51^{\circ} 39^{\prime} \mathrm{W}\right)$, sampled in the early $1990 \mathrm{~s}$, and $D$. willistoni Wip from Northeast Brazil $\left(12^{\circ} 54^{\prime} \mathrm{S}, 38^{\circ} 19^{\prime} \mathrm{W}\right)$, sampled in the 1960s. The strains of $D$. willistoni were chosen since they were previously studied for $P$ element chromosomal positioning (Regner et al. 1996). In the $17 A 2$ strain, only $17 \%$ of the chromocenters analyzed by the authors have a $P$ element inserted, while the Wip strain have $50 \%$ of the chromocenters with $P$ element sites. Some hybridization signals were detected in the euchromatic arms of the Wip strain, but none had a frequency higher than $15 \%$. The mating of $17 \mathrm{~A} 2$ males with Wip females generates offspring with a $26 \%$ hybrid dysgenesis rate at $29^{\circ} \mathrm{C}$ (Regner et al. 1999).

The flies were reared in cornmeal medium (Marques et al. 1966) at constant temperature and humidity $\left(17 \pm 1^{\circ} \mathrm{C} ; 60 \% \mathrm{rh}\right)$.

\section{Extraction OF NuCleic ACIDS}

The DNA of 25 adult flies was extracted by the phenolchloroform method according to Sassi et al. (2005). Total RNA of embryos between $0-18 \mathrm{~h}$ of development was extracted by the Trizol method (Invitrogen).

\section{SYNTHESIS OF CDNA}

The cDNA synthesis was done according to the protocol of M-MLV Reverse Transcriptase enzyme method (Invitrogen) using 2 pmol of the specific mele3- primer for the detection of transposase, 66-kDa repressor and truncated transcripts or meli1+ primer for the detection of antisense transcripts (Table I lists the primer sequences and Fig. 1 depicts the primers applied and their respective binding sites). The cDNA synthesized from Amd-un2 and Amd-bw primers, specific for the $\alpha$-methyldopa gene $(A m d)$ (Tatarenkov et al. 2001), was used as a DNA contamination control in the assay for antisense transcript detection.

\section{AMPLIFICATION OF DNA AND CDNA}

The reaction was carried out in a $15 \mu 1$ volume with $1 \mathrm{U}$ Taq DNA polymerase (Invitrogen) in $1 \mathrm{X}$ polymerase buffer, $2.5 \mathrm{mM}$ of $\mathrm{MgCl}_{2}, 10$ pmol of each primer and $0.6 \mathrm{mM}$ of dNTP mix. The first PCR round of the cDNA amplification was performed with $2 \mu 1$ of cDNA sample and the mele3- primer and meli1+ intron-spanning primers (Fig. 1A). The amplification parameters were a denaturation step at $95^{\circ} \mathrm{C}$ for $5 \mathrm{~min}$, followed by 40 cycles of $95^{\circ} \mathrm{C}$ for $30 \mathrm{~s}, 58^{\circ} \mathrm{C}$ for $30 \mathrm{~s}, 72^{\circ} \mathrm{C}$ for $2.5 \mathrm{~min}$, and a final extension at $72^{\circ} \mathrm{C}$ for $10 \mathrm{~min}$. A $1 \mu 1$ sample of this first PCR amplification was submitted to a second round of amplification with internal primers combined as follows: meli1+ and meli3-, meli2+ and mele3-, meli2+ and meli3- (Table I; Figs. 1B, 1C, 1D), where meli1+, meli2+ and meli3- are intron-spanning primers. The cycle parameters for the second amplification were a denaturation step at $95^{\circ} \mathrm{C}$ for $5 \mathrm{~min}$, followed by 40 cycles at $95^{\circ} \mathrm{C}$ for $1 \mathrm{~min}$, $56^{\circ} \mathrm{C}$ for $1 \mathrm{~min}, 72^{\circ} \mathrm{C}$ for $1 \mathrm{~min}$, and a final extension at $72^{\circ} \mathrm{C}$ for $10 \mathrm{~min}$.

The parameters of amplification of the Amd cDNA were a denaturation step at $94^{\circ} \mathrm{C}$ for $7 \mathrm{~min}$, followed by 40 cycles at $94^{\circ} \mathrm{C}$ for $1 \mathrm{~min}, 56^{\circ} \mathrm{C}$ for $30 \mathrm{~s}, 72^{\circ} \mathrm{C}$ for $1 \mathrm{~min}$, and a final extension at $72^{\circ} \mathrm{C}$ for $10 \mathrm{~min}$.

Thirty nanograms of genomic DNA were used for PCR amplification with the M-IR primers (Table I). The amplification parameters were a denaturation step at $95^{\circ} \mathrm{C}$ for $5 \mathrm{~min}$, followed by 40 cycles at $95^{\circ} \mathrm{C}$ for $40 \mathrm{~s}, 55^{\circ} \mathrm{C}$ for $40 \mathrm{~s}, 72^{\circ} \mathrm{C}$ for $1.5 \mathrm{~min}$, and a final extension at $72^{\circ} \mathrm{C}$ for $10 \mathrm{~min}$.

\section{SOUTHERN BLOT}

The first amplification product, with meli1+ and mele3primers, was submitted to a Southern blot procedure. The gel preparation was carried out following Sambrook et al. (1989). The hybridization, stringency washes and detection reaction followed the Gene Images Labeling kit ${ }^{\circledR}$ and CPD-Stars Detection Module ${ }^{\circledR}$ (Amersham Biosciences). The probe used was the complete canonical $P$ element sequence labeled with fluorescein, used according to the Gene Images Labeling kit ${ }^{\circledR}$ (Amersham Biosciences) specifications. 
TABLE I

PCR primers used.

\begin{tabular}{c|c|c}
\hline Primer & Sequence (5'-3') & $\begin{array}{c}\text { Position in canonical } \\
P \text { element of } D \text {. melanogaster } \\
\text { (GenBank accession code X06779) }\end{array}$ \\
\hline Meli1+* & TACACAAACAGAGTCCTGTT & $431-442,501-508$ \\
\hline Meli2+* & GTATATCAGAATCAAAAACCTG & $1157-1168,1222-1231$ \\
\hline Meli3- * & CATTTCTGTATTCCTGGCTATT & $2154-2138,1947-1943$ \\
\hline Mele3- $*$ & GTTTATCAACATCGACGTTTC & $2581-2561$ \\
\hline M-IR $* *$ & CATAAGGTGGTCCCGTCG & $1-31,2907-2877$ \\
\hline
\end{tabular}

*Haring, Hagemann and Pinsker 1998. **Haring, Hagemann and Pinsker 1995.
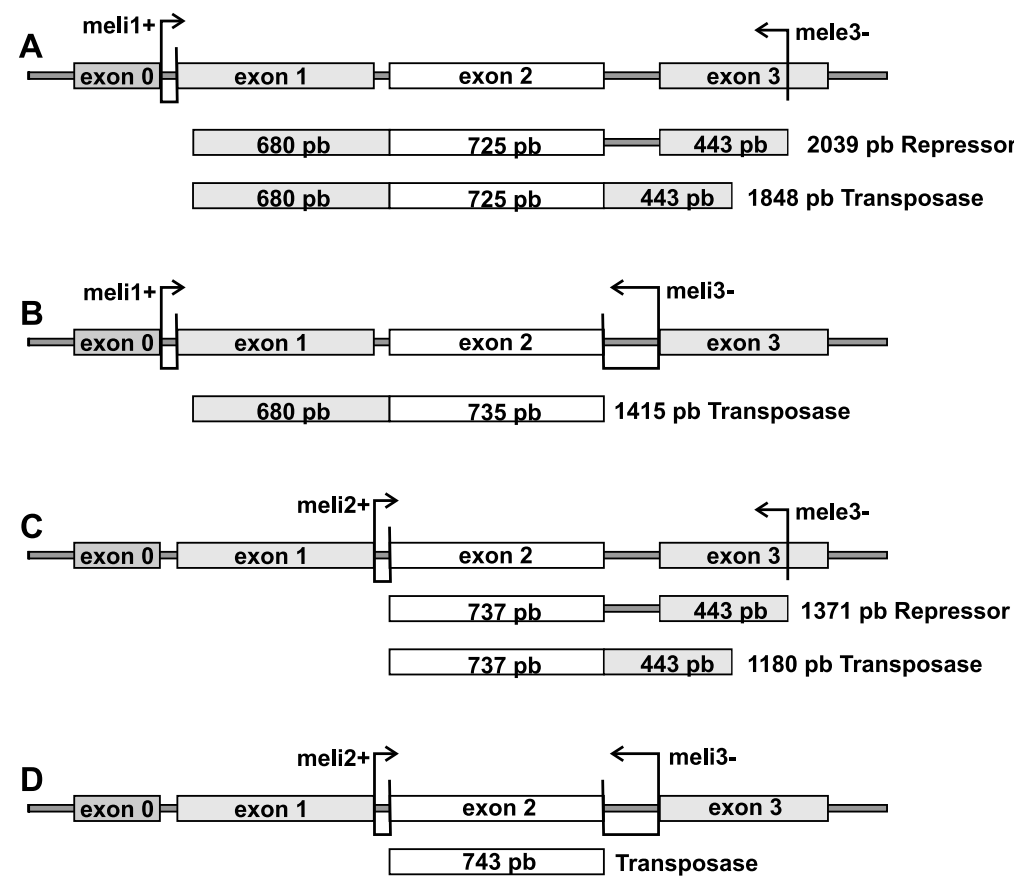

Fig. 1 - Map of the canonical $P$ element showing exons, introns and primers binding sites used in RT-PCR. (A) meli1+ and mele3- primer binding sites and the probable fragments amplified in RT-PCR amplification. (B) meli1+ and meli3- primer binding sites and the probable fragments amplified in RT-PCR amplification. (C) meli2+ and mele3- primer binding sites and the probable fragments amplified in RT-PCR amplification. (D) meli2 + and meli3- primer binding sites and the fragment and the probable fragments amplified in RT-PCR amplification.

\section{SEQUENCING}

The fragments obtained by RT-PCR were sliced off the $0.8 \%$ agarose gel and purified with GFX PCR DNA and Band Gel Purification kit ${ }^{\circledR}$ (Amersham Biosciences) according to the supplier's instructions. The purified DNA was sequenced in a MegaBACE 500 automatic sequencer using the DYEnamic ET kit ${ }^{\circledR}$ (Amersham Biosciences) and the same specific sense and antisense primers used in the PCR amplification were used for dideoxy chaintermination reaction. Sequence identity was confirmed in BlastN (http://www.ncbi.nlm.nih.gov/). The confidence consensus of multiple reads was obtained by analysis of the Staden Package Gap 4 program (Staden 1996). The sequences were then aligned in the MultAlin program (Corpet 1988), according to the default system parameters. 


\section{RESULTS}

\section{Detection of Putative Transcripts}

OF TRANSPOSASE AND 66-KDA REPRESSOR

IN EMBRYOs OF D. melanogaster AND D. willistoni

By RT-PCR, we identified a putative transcript of the transposase enzyme and of the $66-\mathrm{kDa}$ repressor in D. willistoni and D. melanogaster embryos. The 743bp fragment was amplified with the meli2+ and meli3primers in both species (Fig. 1D; Fig. 2, indicated by a narrow arrow). This fragment corresponds to transcripts that have experienced IVS2 and IVS3 splicing, and would thus code for the functional transposase enzyme (GenBank accession codes DQ486674 and DQ486675).

Two amplification products were expected in a RTPCR using meli2+ and mele3- primers: 1180 and 1371bp (Fig. 1C), corresponding to the spliced and unspliced IVS3 transcripts, respectively. In Figure 2, we observe only the unspliced IVS3 fragment (indicated by an arrowhead), a result which was confirmed by partial sequencing of the D. melanogaster fragment. We infer that the transcription of the $66-\mathrm{kDa}$ repressor is higher than the transcription of the transposase, previously identified with the PCR with meli2+ and meli3- primers.

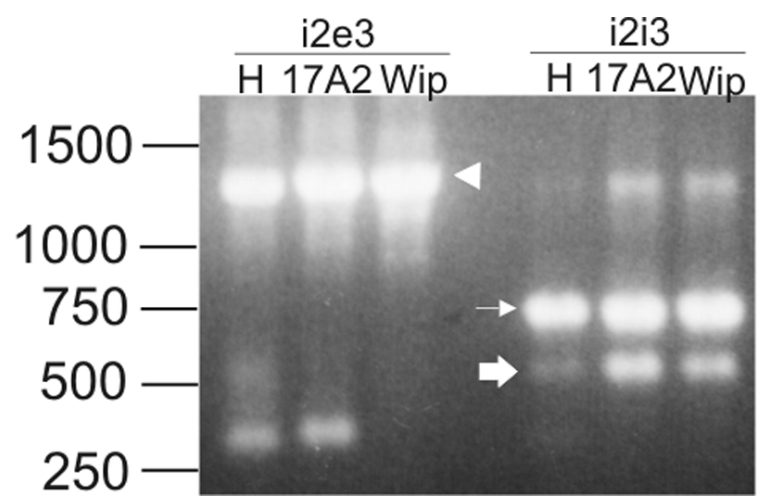

Fig. 2 - Agarose gel electrophoresis with RT-PCR amplification products from embryos of D. melanogaster $(\mathrm{H})$ and $D$. willistoni (17A2 and Wip). The first step of cDNA amplification was carried out with meli1+ and mele3- primers. (i2e3) PCR reamplification with meli2+ and mele3- primers. (i2i3) PCR reamplification with meli2+ and meli3- primers. The narrow arrow indicates the transposase fragment; the arrowhead indicates the $66-\mathrm{kDa}$ transposase repressor fragment; the thick arrow indicates a fragment with truncated exon 2. A 1-kb DNA ladder is depicted on the left.

\section{Alternative Splicing}

A 572-bp fragment was amplified by meli2+ and meli3- primers (Fig. 2, indicated by a thick arrow GenBank accession codes DQ486676, DQ486677 and DQ486678). This sequence lost 198-bp of the 3' region of exon 2 (1742-1941 nt of canonical $P$ element), but maintained its splicing donor site (position $1947 \mathrm{nt}$ of the canonical $P$ element) after undergoing the IVS3 splice.

\section{Differential TRANSCRiption BetweEn Species}

The transcriptional differences between the species were more evident when PCR primers that amplify longer sequences were used. Figure 3 displays the amplification products obtained with the meli1+ primer, combined with the mele3- or the meli3- primers (Figs. 1A and B display the expected amplification products).

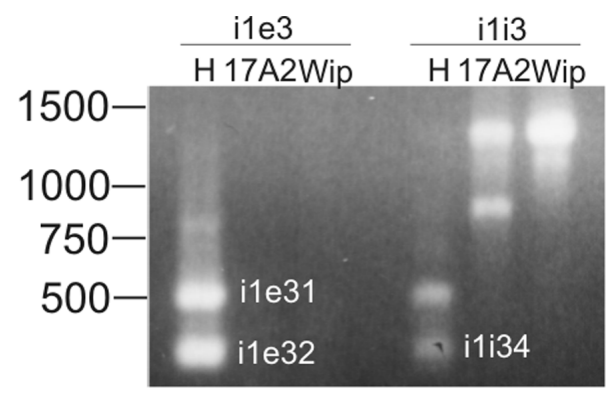

Fig. 3 - Agarose gel electrophoresis with RT-PCR products from embryos of D. melanogaster $(\mathrm{H})$ and D. willistoni (17A2 and Wip). The first step of cDNA amplification was carried out with meli1+ and mele3-primers. (i1e3) RT-PCR with meli1+ and mele3-primers. (i1i3) PCR reamplification with meli1+ and meli3- primers. The arrow indicates the transposase fragment. The fragments indicated by ile31, i1e32 and i1i34 were gel-purified and sequenced. A 1-kb DNA ladder is depicted on the left.

When meli1+ and meli3- were used in the RTPCR amplification, the transposase fragment was visible only in D. willistoni strains (Fig. 3, indicated by an arrow), not in D. melanogaster. In contrast, truncated transcripts were more evident in D. melanogaster when both combinations of primers were used, as compared to D. willistoni (Fig. 3).

This differential expression between the species appears to result from the larger number of truncated $P$ element sequences in the D. melanogaster genome as compared to $D$. willistoni, determined by a genomic 
PCR with the M-IR primer (Fig. 4, M-IR). This primer anneals in the ITRs and amplifies the element across the entire length.

The greater number of truncated sequences related to $P$ element in D. melanogaster also promotes PCR primer competition, as the complete sequence is not realized in the agarose gel (Fig. 4, indicated by an arrowhead).

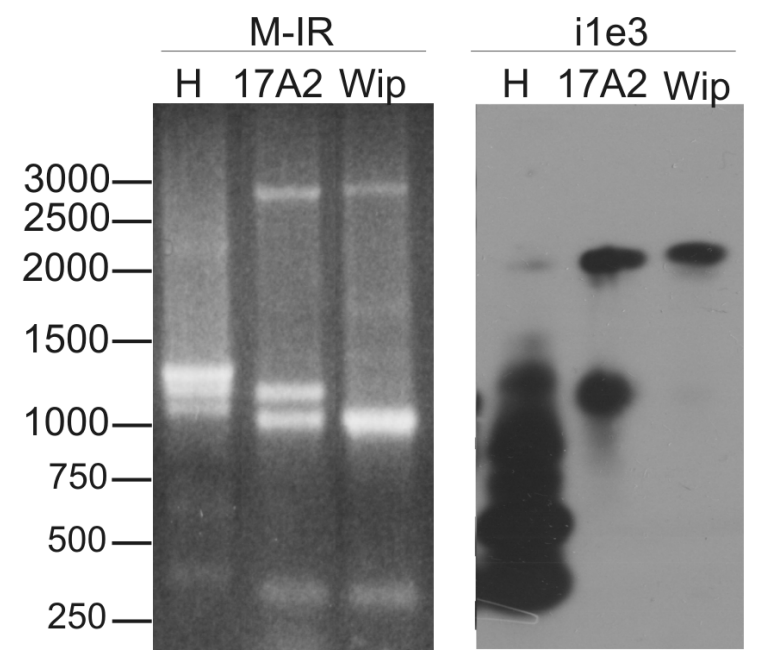

Fig. 4 - Comparison of the fragments obtained from PCR amplification of adult genomic DNA and the fragments obtained from RT-PCR of embryos of D. melanogaster $(\mathrm{H})$ and D. willistoni (17A2 and Wip). (M-IR) Agarose gel electrophoresis with genomic PCR products with M-IR primer. (i1e3) Southern blot, using the canonical $P$ element as probe, of the RT-PCR amplification with meli1+ and mele3- primers. The arrowhead indicate the complete $P$ element sequence and the narrow arrow the repressor of $66-\mathrm{kDa}$ fragment. A $1-\mathrm{kb}$ DNA ladder is shown on the left.

Figure 4 displays a comparison of the amplification fragments obtained with the M-IR primer and genomic DNA as template and the fragments obtained with the primers meli1+ and mele3- and cDNA as template, emphasizing the presence and transcription of truncated $P$ element sequences in the $D$. melanogaster genome. The Southern blot procedure (Fig. 4, ile3) also permitted the visualization of fragments not apparent in Figure 3 (i1e3), including the expected 2039-bp fragment (Fig. 1A; Fig. 4, indicated by an arrow), which encodes the 66-kDa repressor. This discrepancy may derive from PCR primer competition among the high number of transcribed sequences related to the $P$ element.
Since truncated sequences of the $P$ element are potential repressors of transposition (Pinsker et al. 2001), three of the highly expressed fragments in $D$. melanogaster were sequenced. They are indicated as i1e31, i1e32 and i1i34 in Figure 3 and 377, 611 and $284 \mathrm{nt}$ of their sequence were determined, respectively (GenBank accession codes DQ486679, DQ486680 and DQ486681). The sequences align with 3' exon 1 region, which is also present in the KP repressor sequence (Black et al. 1987), but they show little nucleotide conservation. The ile 32 sequence has a duplication of the 5 ' exon 1 region, and the disparity of the fragment size estimated in the agarose gel and the sequence determinants can be the result of a secondary structure acquired by the sequence.

\section{Presence of Antisense $P$ Element Transcripts DURING EMBRYOGENESIS}

The PCR procedure using total embryo cDNA, synthesized starting from a sense primer (meli1+), suggested the presence of antisense transcripts (Fig. 5) in embryos of both species.

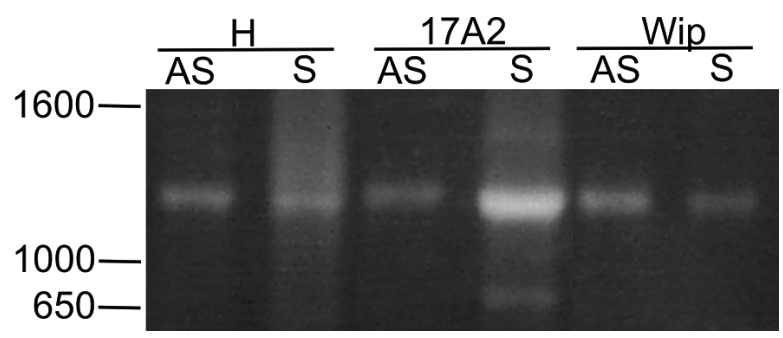

Fig. 5 - Agarose gel electrophoresis of sense and antisense $P$ element fragments obtained by RT-PCR of embryos of D. melanogaster $(\mathrm{H})$ and $D$. willistoni (17A2 and Wip). The sense cDNA was synthesized starting from the meli1+ sense primer and the antisense cDNA was synthesized starting from mele3- antisense primer. The first cDNA amplification was done with meli1+ and mele3- primers and the reamplification reaction with meli2 + and mele3- primers. (AS) Antisense fragments. (S) Sense fragments. A 1-kb DNA ladder is shown on the left.

Unlike the $P$ element, no transcript amplification was observed in the total embryo cDNA synthesized starting from the sense primer Amd-un2 of the Amd gene (data not shown), suggesting the absence of antisense transcripts of the Amd gene and of DNA contamination in the RNA sample. 


\section{DISCUSSION}

The present work aimed to characterize the transcription of $P$ element sequences during embryogenesis of one recently invaded species, $D$. melanogaster, as well as in D. willistoni, a long-standing host of this transposable element, and obtain data about the antisense transcription of $P$ element comparing specifically the two strains of D. willistoni. The work of Haring et al. (1998) proposes the utilization of a combination of four primers to detect the transposase and the $66-\mathrm{kDa}$ repressor. Three of these primers anneal only in spliced sequences, assuring that only cDNA sequences are used as template and also makes it possible to distinguish the transcripts of the transposase and the 66-kDa repressor by the alternative splicing of the IVS3 intron. Using this procedure, we detected transcription of the transposase gene and the 66-kDa repressor in embryos of the studied strains. The absence of transposase transcripts in the amplification using meli2+ and mele3- primers, which was designed to reveal transcripts of both the transposase and the $66-\mathrm{kDa}$ repressor, suggests that there is a greater number of transcripts of the $66-\mathrm{kDa}$ repressor available, as this transcript was more readily used as the template in the RT-PCR reaction. However, transcription of the transposase is specific to germline cells, at least in adults, and these cells are less well represented in the sample than somatic cells.

It is believed that the $66-\mathrm{kDa}$ repressor can bind to $P$ element cleavage sites and block subsequent binding of the transposase enzyme, thus avoiding excision of the TE (Gloor et al. 1993, Laski et al. 1986). Additionally, antisense transcripts and polypeptides encoded by truncated copies offer alternative hypotheses to explain how $P$ element mobilization can be silenced (Rasmusson et al. 1993, Simmons et al. 1996). These authors tested a group of antisense $P$ element constructs and showed that these are bona fide repressors of pupal lethality, a condition established by the existence of $P$ element sequences in which the IVS3 intron is deleted. These mutated sequences allow transcription of the transposase only, not the 66-kDa repressor, even in somatic cells (Engels et al. 1987). In these studies, the antisense $P$ element sequences were inserted in embryos by a transformation procedure while, in the present work, we suggested the synthesis of antisense $P$ element in un-manipulated organisms.

Antisense transcriptional silencing or RNA interference (RNAi) has been described for other TEs (Kleckner et al. 1996, Joanin et al. 1997, Jensen et al. 1999a). In D. hydei (Lankenau et al. 1994) and species of the repleta group (Almeida and Carareto 2004), two antisense transcripts of TE micropia, starting from an internal promoter, can be expressed in a testis-specific fashion. These antisense transcripts are not expressed in D. melanogaster, suggesting that D. melanogaster has developed a different mechanism of regulation than $D$. hydei. In our work, two distantly related species, one of the melanogaster group and the other of the willistoni group, shared an antisense $P$ element transcript of a similar size, suggesting the conservation of the transcription of the antisense sequence and its implied importance for the organism.

In further support of the idea that antisense transcripts regulate transposon mobilization in Drosophila embryos, Blumenstiel and Hartl (2005) proposed that siRNAs (small interfering RNA, composed of dsRNA of 21-25 nt) homologous to the Penelope TE are maternally loaded into embryos of $D$. virilis and act as a silencing machinery against Penelope and other unrelated TEs.

Moreover, $P$ element regulation relies on a chromosomal component. Ronsseray et al. $(1991,1996)$ suggested that the insertion of the $P$ element in telomericassociated sequence on the $\mathrm{X}$ chromosome of D. melanogaster strongly promotes the induction of the cytotype inhibitor. The authors also showed that this capacity is sensitive to mutant alleles of the gene $\mathrm{Su}$ (var)205, which encodes the Heterochromatin Protein 1, involved in the heterochromatin formation, and of the gene aubergine, which encodes the AUBERGINE protein, a protein that favors $P$ element silencing in a heterochromatin loci-dependent manner, through a mechanism triggered by RNAi (Aravin et al. 2001, Reiss et al. 2004). Also, Josse et al. (2007) determined the sensitivity of the P cytotype to mutations in the gene $\mathrm{Su}$ (var) 205 and in the gene aubergine, piwi, armitage and homeless, which encodes proteins that trigger a silencing mechanism dependent on antisense transcripts. The same authors verified that the $\mathrm{P}$ cytotype could be established in the female germline in only six generations. 
The TEs gypsy, Zam and Idefix of Drosophila are also regulated by heterochromatic loci: the flamenco locus of gypsy (Sarot et al. 2004), and the COM locus of Zam and Idefix (Desset et al. 2003). PIWI is one of the proteins involved in the RNAi-mediated mobilization silencing of these TEs (Desset et al. 2003, Sarot et al. 2004). Through immunopurification, various kinds of TEs were observed as being linked to PIWI, as were sense and antisense sequences of the TE roo (Saito et al. 2006). It is interesting that this protein is strongly expressed in ovaries and early embryos, including the pole cells where mobilization of the $P$ element promotes the gonadal atrophy that characterizes hybrid dysgenesis.

When evaluating the two strains of $D$. willistoni with regard to their heterochromatic sites and the silencing mechanisms described previously, we expected that the Wip strain would have a more efficient RNAi silencing mechanism than the $17 \mathrm{~A} 2$ strain, in which $P$ elements are preferentially arranged in euchromatic sites. However, we did not observe significant qualitative expression differences between the two strains of $D$. willistoni by RT-PCR. Considering the low percentage of hybrid dysgenesis $(26 \%)$ observed in their offspring (Regner et al. 1999), we can suppose that the 17A2 strain has already developed a mobilization control for the $P$ element and, as described by Josse et al. (2007), it is possible to register variegation in ovaries when silencing is incomplete. Yet, as cited by Johnson (2008) in a recent commentary about transposon silencing, one or two insertions of the $P$ element at the telomeric silencing site can efficiently suppress as many as 80 homologues copies elsewhere in the genome. Quantitative evaluation of the transposase and antisense transcripts is necessary for a better comprehension of the mechanisms and to shed more light on the possibility that it really acts in the repression of mobilization.

In the present work, truncated transcripts related to the $P$ element and amplified by RT-PCR were sequenced. These truncated copies could function as a stable source of repressive proteins (Pinsker et al. 2001), by creating heteromultimers (Rio 1999), or by triggering a mechanism of homology-dependent silencing (Jensen et al. 1999a, b). A greater number of truncated copies were amplified in D. melanogaster than in D. willistoni. This difference seems to reflect the sequences avail- able in the genome of each species, rather than differential expression. Apart from this, the larger number of truncated copies exhibited by D. melanogaster demonstrates the process of stabilization of the $P$ element in the genome of this species (Kidwell and Lisch 2001). It is possible that truncated copies that play an important role in the regulation of TE mobility would be maintained in the genome, while others would be lost due to successive mutations. When the two strains of D. willistoni are observed more carefully, it is possible to infer the same: the 17A2 strain, where we can visualize one extra truncated sequence as compared to the Wip strain (Fig. 4, M-IR), is under a process of silencing that is more recent than that of the Wip strain.

Three highly expressed truncated $P$ element transcripts from $D$. melanogaster were sequenced. The most conserved region among them is an exon 1 sequence, also present in the KP repressor. However, we do not know whether these transcripts maintain the same DNA binding and dimerization motifs of the KP repressor (Lee et al. 1996, 1998), two important sites for the inhibition of transcription, because the ORF0, which encodes these motifs, was not amplified and sequenced. Independent of the sequence conservation, the activity of the truncated transcripts as repressors of mobility should be tested, as the UP1 and NP2 sequences, with 212 and 159 amino acids similar to the KP, do not silence $P$ element mobilization (Simmons et al. 1996). Investigation of these sequences could also be valuable due to their high expression in embryos of $D$. melanogaster and because non-translatable sequences can act via a homology-dependent silencing mechanism, related to the copy number and homology of the sequence, as suggested by the $I$ retrotransposon (Jensen et al. 1999a, b).

In addition, we observed a truncated sequence shared by $D$. willistoni and $D$. melanogaster species that could be the result of another horizontal transfer between these species, similar to that suggested for the complete $P$ element (Daniels et al. 1990). It is also possible to conjecture that we detected a deletion hotspot or a splicing variant site in the sequence of $P$ element. Variant splicing sites in $P$ element were already described in D. melanogaster (Chain et al. 1991), D. bifasciata and D. helvetica (Haring et al. 1998). These 
sites, however, lie within the IVS3 intron sequence, while our data suggest an alternative splicing site into exon 2, at 1741 nt of the canonical $P$ sequence (GenBank accession code X06779). The transcripts described by Haring et al. (1998), originated by variant splicing, are 120 and 105-bp longer than the transposase transcript, and were not observed in embryos of either species examined in our study, in spite of their nucleotide conservation. The ability of these splicing variant sequences to transpose and their capacity to function as a repressor are still unknown.

The presence of a putative transposase transcript during embryogenesis of a non- hypermutable strain indicates the existence of a post-transcriptional control mechanism, possibly including the $66-\mathrm{kDa}$ repressor, the truncated copies, mainly in D. melanogaster, and the antisense transcripts. The last option is the most recently proposed mechanism of $P$ element silencing and the role of these transcripts in the repressor cytotype, which should be further investigated. The inclusion of D. willistoni in studies of $P$ element regulation could improve the understanding of silencing mechanisms, as well as how they are broken in the offspring of some strains, resulting in hybrid dysgenesis.

\section{ACKNOWLEDGMENTS}

We are grateful to Dr. Marco Silva Gottschalk for his revision of the manuscript and for his help with the figures. This project was supported by Conselho Nacional de Desenvolvimento Científico e Tecnológico (CNPq), Coordenação de Aperfeiçoamento de Pessoal de Nível Superior (CAPES) and Fundação de Amparo à Pesquisa do Estado do Rio Grande do Sul (FAPERGS).

\section{RESUMO}

O elemento $P$ é um dos elementos transponíveis (TE) mais amplamente estudado. Sua mobilização causa a disgenesia do híbrido que foi primeiramente descrita em D. melanogaster. Apesar dos estudos sobre o elemento $P$ terem sido realizados principalmente com $D$. melanogaster, acredita-se que $D$. willistoni foi a espécie hospedeira original deste TE e que ele se transpôs para o genoma de D. melanogaster por transferência horizontal. Nosso estudo visou a comparação do comportamento transcripcional do elemento $P$ em embriões de $D$. melanogaster, que é a hospedeira recente, com o de embriões de duas linhagens de $D$. willistoni, uma espécie que é, a longo tempo, hospedeira do elemento $P$. Em ambas as espécies foram detectados transcritos potenciais da transposase, enzima responsável pela mobilização do TE, bem como transcritos do repressor de 66-kDa e de seqüências truncadas e antisenso, os quais podem ter a habilidade de prevenir a mobilização de TEs. Os transcritos truncados refletem os elementos $P$ truncados presentes no genoma das linhagens e cujo número parece relacionado com o tempo de invasão do genoma pelo TE. Nenhuma diferença qualitativa de transcritos antisenso foi observada entre as espécies, mesmo na linhagem de $D$. willistoni com alta freqüência de elemento $P$ heterocromático.

Palavras-chave: Drosophila, D. willistoni, disgenesia do híbrido, RNAi, elemento $P$, elemento transponível.

\section{REFERENCES}

Almeida LM AND CARAReto CM. 2004. Identification of two subfamilies of micropia transposable element in species of the repleta group of Drosophila. Genetica 121: $155-164$.

ARAVIN AA, NAUmova NM, TUlin AV, VAGin VV, Rozovsky YM AND GvozdeV VA. 2001. Doublestranded RNA-mediated silencing of genomic tandem repeats and transposable elements in the D. melanogaster germline. Curr Biol 11: 1017-1027.

BLACK DM, JACKSON MS, KIDWELL MG AND DOVER GA. 1987. KP elements repress P-induced hybrid dysgenesis in Drosophila melanogaster. EMBO J 6: 4125-4135.

BLUMENSTIEL JP AND HARTL BL. 2005. Evidence for maternally transmitted small interfering RNA in the repression of transposition in Drosophila virilis. Proc Natl Acad Sci USA 102: 15965-15970.

Bregliano JC AND KidWEll MG. 1983. Hybrid dysgenesis determinants. In: SHAPIRO JA (Ed), Mobile Genetic Elements. Academic Press, New York, p. 363410.

BROOKFIELD JF. 1991. Models of repression of transposition in P-M hybrid dysgenesis by $\mathrm{P}$ cytotype and by zygotically encoded repressor proteins. Genetics 128: 471-486.

Chain AC, Zollman S, Tseng JC And Laski FA. 1991. Identification of a cis-acting sequence required for germ line-specific splicing of the $P$ element ORF-2ORF-3 intron. Mol Cell Biol 11: 1538-1546. 
Clark JB AND Kidwell MG. 1997. A phylogenetic perspective on $P$ transposable element evolution in Drosophila. Proc Natl Acad Sci USA 94: 11428-11433.

CORPET F. 1988. Multiple sequence alignment with hierarchical clustering. Nucleic Acids Res 16: 10881-10890. Technical tips online (http://prodes.toulouse.inra.fr/multalin/multalin.html).

Crozatier M, Vaury C, Busseau i, Pelisson A AND BUCHETON A. 1988. Structure and genomic organization of $I$ elements involved in I-R hybrid dysgenesis in Drosophila melanogaster. Nucleic Acids Res 16: 9199-9213.

Daniels SB, Peterson KR, Strausbaugh LD, KidWELL MG AND CHOVNICK A. 1990. Evidence for horizontal transfer of the $P$ transposable element between Drosophila species. Genetics 24: 339-355.

Desset S, Conte C, Dimitri P, Calco V, Dastugue B AND VAURY C. 2003. COM, a heterochromatic locus governing the control of independent endogenous retroviruses from Drosophila melanogaster. Genetics 164: 501-509.

ENGELS WR. 1989. P elements in Drosophila melanogaster. In: BERG DE AND Howe MM (Eds), Mobilie DNA. American Society for Microbiology Publication, Washington DC, p. 437-484.

Engels Wr, Benz WK, Preston CR, Graham PL, Phillis RW AND Robertson HM. 1987. Somatic effects of $P$ element activity in Drosophila melanogaster: pupal lethality. Genetics 117: 745-757.

Evgen'ev MB, Zelentsova H, Shostak N, Kozitsina M, Barskyi V, Lankenau DH and Corces VG. 1997. Penelope, a new family of transposable elements and its possible role in hybrid dysgenesis in Drosophila virilis. Proc Natl Acad Sci USA 94: 196-201.

GLOor GB, Preston CR, Johnson-Schlitz DM, NAsSif NA, Phillis RW, BEnz WK, Robertson HM AND ENGELS WR. 1993. Type I repressors of $P$ element mobility. Genetics 135: 81-95.

Haring E, Hagemann S And Pinsker W. 1995. Different evolutionary behaviour of $P$ element subfamilies: M-type and O-type elements in Drosophila bifasciata and D. imaii. Gene 163: 197-202.

Haring E, Hagemann S And Pinske RW. 1998. Transcription and splicing patterns of $\mathrm{M}$ - and O-type $P$ elements in Drosophila bifasciata, D. helvetica, and Scaptomyza pallida. J Mol Evol 46: 542-551.
Jensen S, Gassama MP and Heidmann T. 1999a. Cosuppression of $I$ Transposon Activity in Drosophila by $I$-Containing Sense and Antisense Transgenes. Genetics 153: $1767-1774$.

Jensen S, Gassama MP And Heidmann T. 1999b. Taming of transposable elements by homology-dependent gene silencing. Nat Genet 21: 209-212.

JoAnin P, Hershberger RJ, Benito MI AND WALbot V. 1997. Sense and antisense transcripts of the maize MuDR regulatory transposon localized by in situ hybridization. Plant Mol Biol 33: 23-36.

JOHNSON L. 2008. The extraordinary epigenetics of a transposon trap. Heredity 100: 5.

Josse T, Teysset L, Todeschini AL, Sidor C, AnXoLABÉHÈre D AND RonsSERAY S. 2007. PLoS Genet (doi:10.1371/journal.pgen.0030158.eor).

KIDWELl JF AND KIDWELl MG. 1979. Dynamics of natural selection on a lethal fourth chromosome of Drosophila. Twelve-generation study of experimental populations of D. melanogaster. J Hered 70: 123-126.

KIDWELL MG. 1977. Reciprocal differences in female recombination associated with hybrid dysgenesis in Drosophila melanogaster. Genet Res 30: 77-88.

KIDWell MG AND Lisch DR. 2001. Perspective: Transposable elements, parasitic DNA, and genome evolution. Evolution 55: 1-24.

Kleckner N, Chalmers RM, Kwon D, Sakai J And Bolland S. 1996. Tn10 and IS10 transposition and chromosome rearrangements: mechanism and regulation in vivo and in vitro. Curr Top Microbiol Immunol 204: 49-82.

Lankenau S, Corces VG and Lankenau DH. 1994. The Drosophila micropia retrotransposon encodes a testis-specific antisense RNA complementary to reverse transcriptase. Mol Cell Biol 14: 1764-1775.

LAski FA, Rio DC And RUBin GM. 1986. Tissue specificity of Drosophila $P$ element transposition is regulated at the level of mRNA splicing. Cell 44: 7-19.

LeE CC, Mul YM AND Rio DC. 1996. The Drosophila $P$-element KP repressor protein dimerizes and interacts with multiple sites on $P$-element DNA. Mol Cell Biol 16: 5616-5622.

LeE CC, Beall EL AND Rio DC. 1998. DNA binding by the KP repressor protein inhibits $P$-element transposase activity in vitro. EMBO J 17: 4166-4174.

Loreto EL, Da Silva LB, Zaha A and Valente VL. 1998. Distribution of transposable elements in neotropical species of Drosophila. Genetica 101: 153-165. 
LOZOVSKAYA ER, SCHEINKER VS AND EVGEN'EV MB. 1990. A hybrid dysgenesis syndrome in Drosophila virilis. Genetics 126: 619-623.

Marques EK, NApp M, Winge H And Cordeiro AR. 1966. A corn meal, sorbean flour, wheat germ medium for Drosophila. Dros Inf Serv 41: 187.

MisRa S AND Rio DC. 1990. Cytotype control of Drosophila $P$ element transposition: the $66-\mathrm{kDa}$ protein is a repressor of transposase activity. Cell 62: 269-284.

Petrov DA, Schutzman JL, HARTL DL AND LozovsKAYA ER. 1995. Diverse transposable elements are mobilized in hybrid dysgenesis in Drosophila virilis. Proc Natl Acad Sci USA 92: 8050-8054.

Pinsker W, Haring E, Hagemann S And Miller WJ. 2001. The evolutionary life history of $P$ transposons: from horizontal invaders to domesticated neogenes. Chromosoma 110: 148-158.

RASMUSSON KE, RAYMOND JD AND SIMMONS MJ. 1993. Repression of hybrid dysgenesis in Drosophila melanogaster by individual naturally occurring $P$ elements. Genetics 133: 605-622.

Regner lp, Pereira MS, Alonso CE, Abdelhay E AND VAlEnte VL. 1996. Genomic distribution of $P$ elements in Drosophila willistoni and a search for their relationship with chromosomal inversions. J Hered 87: 191-198.

Regner LP, ABdelhay E, Rodhe C, Rodrigues JS AND VALENTE VL. 1999. Temperature-dependent gonadal hybrid dysgenesis in Drosophila willistoni. Genet Mol Biol 22: 205-211.

Reiss D, Josse T, AnXolabehere D And Ronsseray S. 2004. Aubergine mutations in Drosophila melanogaster impair $P$ cytotype determination by telomeric $P$ elements inserted in heterochromatin. Mol Genet Genomics 272: 336-343.

RIO DC. 1999. Molecular mechanisms regulating Drosophila $P$ element transposition. Annu Rev Genet 24: 543-578.

Ronsseray S, LEHMANN M AND ANXolabéhÈre D. 1991. The maternally inherited regulation of $P$ elements in Drosophila melanogaster can be elicited by two $P$ copies at cytological site $1 \mathrm{~A}$ on the $\mathrm{X}$ chromosome. Genetics 129: 501-512.

Ronsseray S, Lehmann M, Nouaud D AND ANXoLABEHERE D. 1996. The regulatory properties of autonomous subtelomeric $P$ elements are sensitive to a
Suppressor of variegation in Drosophila melanogaster. Genetics 143: 1663-1674.

SAito K, Nishida KM, MORI T, KaWAMURA Y, MiYOShi K, NAGAMi T, Siomi H AND Siomi MC. 2006. Specific association of Piwi with rasiRNAs derived from retrotrasnposon and heterochromatic regions in the Drosophila genome. Genes and Dev 20: 2214-2222.

SAmbrook J, Fritsh EF And Maniatis T. 1989. Molecular cloning: a laboratory manual. Cold Spring Harbor, New York.

Sarot E, PAyen-Groschêne G, Bucheton A And PÉLISSON A. 2004. Evidence for a piwi-dependent RNA silencing of the gypsy endogenous retrovirus by the Drosophila melanogaster flamenco gene. Genetics 166: 1313-1321.

SASSi AK, Herédia F, LoReto ELS, VALENTE VLS AND RodHe C. 2005. Transposable elements $P$ and gypsy in natural populations of Drosophila willistoni. Genet Mol Biol 28: 734-739.

Siebel CW AND Rio DC. 1990. Regulated splicing of the Drosophila $P$ transposable element third intron in vitro: somatic repression. Science 248: 1200-1208.

Simmons MJ, RAYMOND JD, GRIMES CD, BELINCO C, HAAKE BC, JORDAN M, LUND C, OJALA TA AND PAPERMASTER D. 1996. Repression of hybrid dysgenesis in Drosophila melanogaster by heat-shock-inducible sense and antisense $P$-element constructs. Genetics 144: 1529-1544.

Simmons MJ, Haley KJ And Thompson SJ. 2002. Maternal transmission of $P$ element transposase activity in Drosophila melanogaster depends on the last $P$ intron. Proc Natl Acad Sci USA 99: 9306-9309.

STADEN R. 1996. The Staden sequence analysis package. Mol Biotechnol 5: 233-241.

TAtarenkov A, Zurovcová M And Ayala FJ. 2001. $D d c$ and Amd sequences resolve phylogenetic relationships of Drosophila. Mol Phylogenet 20: 321-325.

YAnnopoulos G, Stamatis N, Monastirioti M, HATzOPOUlos P AND Louis C. 1987. hobo is responsible for the induction of hybrid dysgenesis by strains of Drosophila melanogaster bearing the male recombination factor 23.5 MRF. Cell 49: 487-495. 